\title{
Investigation of Three Pre-treatment Methods Prior to Nanofiltration Membrane for Palm Oil Mill Effluent Treatment
}

\author{
(Kajian Tiga Kaedah Pra-Rawat Sebelum Membran Penurasan Nano untuk
} Rawatan Efluen Kilang Minyak Sawit)

\author{
MuHAMmad SAID, ABDUl WaHAB MOHAMMAD*, MOHD TUSIRIN MOHD NOR, \\ SiTI ROZAIMAH SHEIKH ABDULLAH \& HASSIMI ABU HASAN
}

ABSTRACT

Palm oil mill effluent (POME) treatment has developed in the last decade. Due to the characteristic and volume of POME, it needed a complete treatment to reduce the pollutant content. Three pre-treatments method, ultrafiltration, adsorption and decantation were applied prior to nanofiltration $(N F)$ membrane. The polyethersulphone membrane, montmorillonite as the adsorbent and modern decanter was investigated in this research. Two types of NF membrane, named NF-1 and NF-ASP30 were used after pre-treatment. The removal of four important parameters were determined i.e. COD, TSS, colour and turbidity. The results showed that the adsorption and UF is better than decantation pre-treatment. The ultrafiltration and adsorption can reduce POME content more than $80 \%$ for all parameter while decantation varied between 40 and $80 \%$. The combination of ultrafiltration and adsorption with both of NF membrane can removed almost all the parameter. But the decantation can only remove the turbidity but not for the rest of the parameters. Besides the POME content, the flux decline for both of NF membrane was also investigated. The flux of NF-1 membrane was higher than NF-ASP3O membrane but NF-ASP was more relative stable for the flux decline. Overall, NF-1 has better performance in flux decline.

Keywords: Adsorption; decantation; nanofiltration; POME; ultrafiltration

ABSTRAK

Rawatan efluen kilang minyak sawit (POME) telah dibangunkan sejak sedekad yang lalu. Disebabkan ciri dan isi padu POME, ia memerlukan satu rawatan yang sempurna untuk mengurangkan kandungan pencemaran. Tiga kaedah pra-rawat iaitu penurasan ultra, penjerapan dan penyiringan telah digunakan sebelum menggunakan membran penurasan nano. Dalam penyelidikan ini, membran polietersalfon, bahan penjerap iaitu montmorilonit dan penyiring moden telah dikaji. Dua jenis membran penurasan nano iaitu NF-1 dan NF-ASP30 telah digunakan selepas kaedah pra-rawat. Penyingkiran empat jenis parameter yang penting, iaitu keperluan oksigen kimia (COD), jumlah pepejal terampai (TSS), warna dan kekeruhan telah ditentukan. Keputusan menunjukkan bahawa penjerapan dan penurasan ultra lebih baik daripada prarawat penyiringsan penurasan ultra dan penjerapam boleh mengurangkan kandungan POME lebih daripada $80 \%$ untuk seтиа parameter manakala penyiringan berubah antara 40 dan $80 \%$. Gabungan penurasan ultra dan penjerapan dengan kedua-dua membran penurasan nano boleh menyingkirkan hampir kesemua parameter, manakala penyiringan hanya boleh menyingkirkan kekeruhan tetapi bukan untuk parameter yang selebihnya. Selain kandungan POME, penurunan fluks untuk kedua-dua membran NF juga dikaji. Fluks membran NF-1 adalah lebih tinggi daripada membran NF-ASP30 tetapi penurunan fluks NF-ASP3O adalah lebih stabil. Secara keseluruhannya, NF-1 mempunyai prestasi yang lebih baik dalam penurunan fluks.

Kata kunci: Penjerapan; penurasan nano; penurasan ultra; penyiringan; POME

\section{INTRODUCTION}

Malaysia and Indonesia have been known as the world leading producer of palm oil. Along with the increasing production of palm oil, the consumption of water also increases. To process one ton of fresh fruit bunches (FFB), it required 5 to 7.5 tons of fresh water and unfortunately, $50 \%$ of this water will end up as a palm oil mill effluent (POME) while the rest is lost as steam boilers and leakage. These wastewaters, if they do not get a good handling, it will potentially contaminate the environment (Ahmad et al. 2003).
POME is a hazardous compound that contains $95-96 \%$ of water, $0.6-0.7 \%$ of oil and $4-5 \%$ of total solids. It is acidic ( $\mathrm{pH} 4-5)$, dark colour and foul smelling. In addition, POME has a high organic content (COD $50000 \mathrm{mg} / \mathrm{L}$ and BOD $25000 \mathrm{mg} / \mathrm{L}$ ). Based on these characteristics, it requires an efficient and inexpensive method for treating POME.

In Malaysia, the common methods that was used to POME are integrated anaerobic and aerobic ponds. The main character of this method required large land and long residence time (Yejian et al. 2008). To reduce the land requirement, some researchers have investigated the 
essential of biological pre-treatment. Some example of biological of pre-treatment of POME are anaerobic fluidized bed (Borja \& Banks 1995), two stage of up-flow anaerobic sludge blanket (Borja et al. 1996), anaerobic digester (Chan et al. 2010), aerobic treatment (Vijayaraghavan et al. 2007), rotating biological contactor (Najafpour et al. 2005) and sludge fixed film bioreactor (Zinatizadeh et al. 2006). Meanwhile to reduce the long residence time, some of the researchers have been investigated the physicalchemical pre-treatment, solvent extraction (Hameed et al. 2003), coagulation (Ahmad et al. 2006), dissolved air flotation ( $\mathrm{Ng}$ et al. 1988), adsorption (Ahmad et al. 2005) and ultrafiltration (Said et al. 2014).

In the last decade, membrane technology has significant development in waste water treatment. Some of researchers have also investigated the membrane technology to treat POME. Membrane filtration has capability to produce clear water in a short time, reduce area and energy consumption. The main weakness of membrane filtration is membrane surface easily fouled. In order to make the filtration duration life longer, it needed the pre-treatment prior membrane filtration (Wah et al. 2002; Wu et al. 2007).

Nanofiltration (NF) is classified between Ultrafiltration (UF) and Reverse Osmosis (RO). It has molecular weight 100-1000D, pore size $0.001-0.01 \mu \mathrm{m}$ and pressure of 20-40 bars. Nanofiltration can be used as pre-treatment prior to reverse osmosis system or to be used as the main equipment after some pre-treatments. Nanofiltration has been applied in various industries including paper mill (Gönder et al. 2011) and pharmaceutical wastewater treatment (Wei et al. 2010), arsenic removal (Ahmed et al. 2010) and desalination (Susanto 2011).

This research was focus on the on investigation of the combination of physical-chemical pre-treatment with nanofiltration membrane for POME treatment. The three technologies: ultra-filtration, adsorption and decantation, are applied for the POME pre-treatment prior to nanofiltration.

\section{MATERIALS AND METHODS}

\section{PALM OIL MILL EFFLUENT (POME)}

Samples of POME were collected from the aerobic pond of West Palm Oil Mill, Carey Island, Klang, Malaysia. The characterisations were conducted to determine the content of chemical oxygen demand (COD), total suspended solid (TSS), colour, turbidity and phenol levels by using a Hach $\mathrm{DR} / 2010$ spectrophotometer. The average value is taken from three repeated experiments. Detailed composition and features of the waste water are summarised in Table 1. The reduction in the solution parameters was calculated by the following:

$$
\mathrm{C}(\%)=\left(\left(1-\frac{C p}{C s}\right)\right) \times 100,
$$

where $\mathrm{C}_{\mathrm{p}}$ is the concentration in the permeate solution and $\mathrm{C}_{\mathrm{s}}$ is the concentration in the feed sample.

TABLE 1. Characterisation of POME

\begin{tabular}{lc}
\hline Parameter & Raw sample of POME \\
\hline COD $(\mathrm{mg} / \mathrm{L})$ & 12,040 \\
TSS $(\mathrm{mg} / \mathrm{L})$ & 3,103 \\
Colour $(\mathrm{PtCo})$ & 54,200 \\
Turbidity (NTU) & 23,750 \\
$\mathrm{pH}$ & 7.43 \\
\hline
\end{tabular}

\section{PRE-TREATMENT METHOD}

Ultrafiltration A polyethersulphone (PES) membrane with molecular weight cut off (MWCO) of $25 \mathrm{kDa}$ was purchased from Sterlitech Corporation. The membrane was located at the bottom of the stirrer cell. The stirred cell (Amicon 8200 , Millipore.co, USA) had a single blade stirrer and was also equipped with an acrylic solution reservoir of 1000 $\mathrm{mL}$. The experiment was conducted by pouring $200 \mathrm{~mL}$ of POME into the Ultrafiltration Amicon 8200. The volume of permeated samples was collected to analyse the contents of COD, TSS, colour and turbidity.

Adsorption Montmorillonite was purchased from the Acros Organics and used without any precondition. The experiment was done in $500 \mathrm{~mL}$ beaker containing 250 $\mathrm{mL}$ of POME. The adsorption process was mixed using stirrer at $300 \mathrm{rpm}$ for $60 \mathrm{~min}$ and after that the stirrer was stopped to let the particulate to settle down for $15 \mathrm{~min}$. The supernatant was sampled for analysis purpose.

Decantation Decanter was purchased from Alfa Laval, India. The decanter was operated at $4200 \mathrm{rpm}$ for $2 \mathrm{~h}$. The liquid and solids are feed along the centre of centre line to a distribution room within bowl. The centrifugal force then causes the suspended solids to settle and accumulate at the bowl and finally fall into the container that was prepared previously. The clarified liquid flows back along the bowl and is discharged at the end of the bowl. During this process, it will separate solution and solids simultaneously. Solids were used as compost while the solution was used as feeding sample for nanofiltration. The clarified liquid was analysed to determine the characteristic of POME.

Nanofiltration In this study, two commercials NF membranes named NF-1 and NF-ASP30 were used and purchased from Amfor Inc., China. Based on the contact angle measurement, the NF-ASP30 is more hydrophobic than NF-1 (Abuhabib et al.2012). The experiment was done in a stainless steel stirred cell (HP 4750) that was purchased from Sterlitech, UK. About $200 \mathrm{~mL}$ of pre-treatment POME was poured into cell. The operation pressure is $10 \mathrm{bar}$ and stirrer on $300 \mathrm{rpm}$. After $150 \mathrm{~min}$, permeate were collected for analysis purpose to determine the levels of COD, TSS, colour and turbidity. 


\section{RESULTS AND DISCUSSION}

PARAMETERS AFTER PRE-TREATMENT

Three different pre-treatment methods were performed to reduce the COD, TSS, colour and turbidity levels from POME. The result is summarized in Table 2. The adsorption and ultrafiltration pre-treatment were observed and can make a significant reducing of COD, TSS, colour and turbidity. The capabilities of PES membrane and montmorillonite as adsorbents are equal. The foulants is trapped on the surface and inside of pore membranes, while the Montmorillonite has surface active that can make a strong bonding to foulants.

From Figure 1, it can be seen that the COD, TSS and colour were efficiently removed by three pre-treatment methods, except for the TSS reducing by decantation process. The ultrafiltration membrane used in this study was made from polyethersulphone that has hydrophobic character. Because of this characteristic, the PES membrane was able to provide a strong chemical reaction with suspended solid and then formed as a cake layer. This phenomenon was explained by Amin et al. (2010). The sulphonyl functional groups of the PES membrane are rigid with a compact structure, so molecules or particles are easily adsorbed on the membrane surface. The cake layer was trapped on the membrane surface which contained most of the small particle including colour and dissolve solids. Figure 2 shows the SEM image of PES membrane.

The capabilities of Montmorillonite to adsorb foulants came from the negative charge of it. This negative charge neutralizes the positive charge of impurities of POME and it will attract and trap on the surface of adsorbent (Ahmaruzzaman 2008). As shown in Figure 3, it can be seen that the surface of montmorillonite was full with foulants.

TABLE 2. The POME content after pre-treatment

\begin{tabular}{lcccc}
\hline Parameter & Raw sample & Ultra filtration & Adsorption & Decantation \\
\hline COD (mg/L) & 12040 & 619 & 416 & 1516 \\
TSS (mg/L) & 3103 & 177 & 645 & 1822 \\
Colour (PtCo) & 54200 & 507 & 105 & 1709 \\
Turbidity (NTU) & 23750 & 4364 & 2203 & 14118 \\
\hline
\end{tabular}

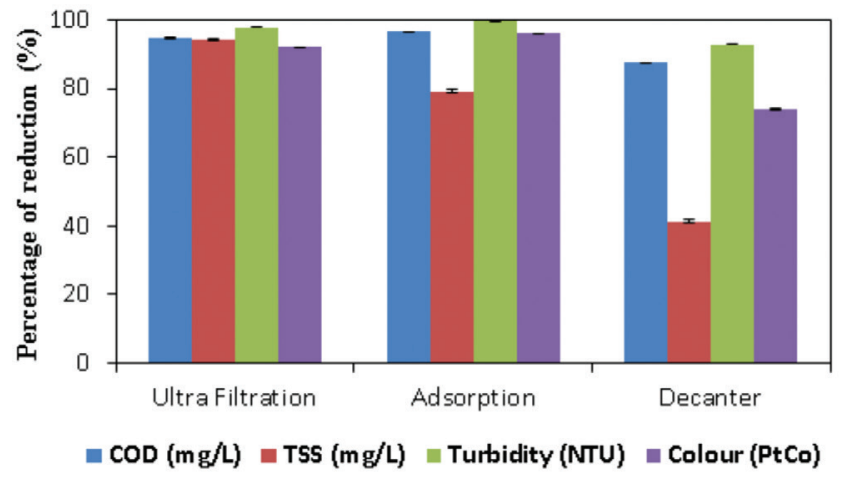

FIGURE 1. The percentage of reduction of POME contents after pre-treatment
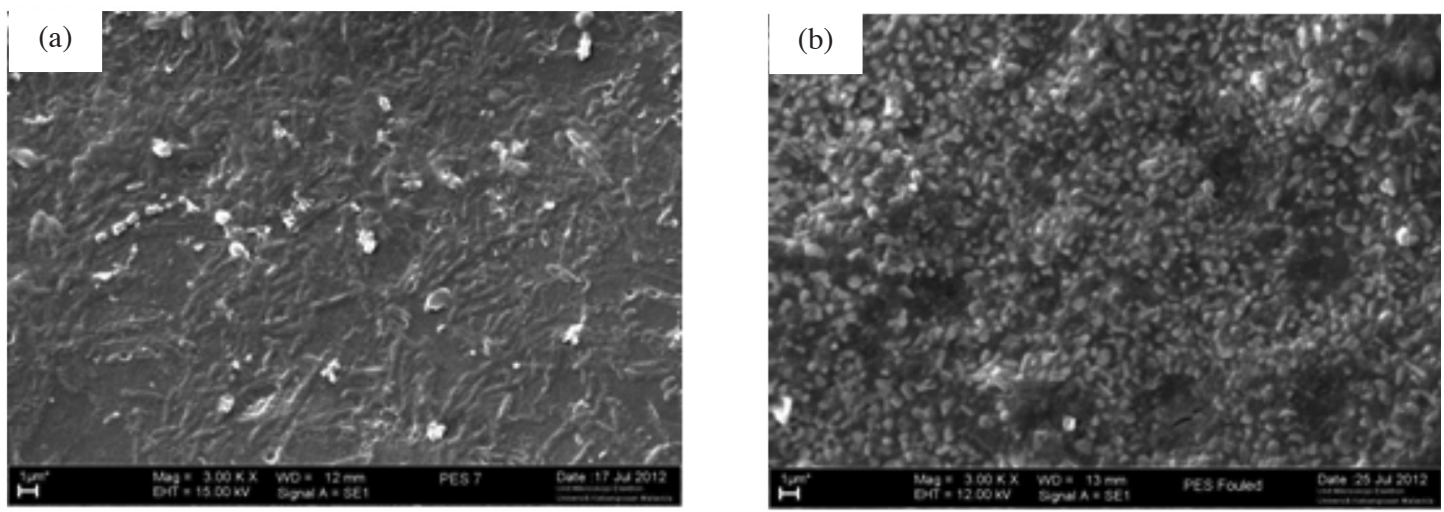

FIGURE 2. The SEM images of PES membrane (a) before treatment and (b) after treatment 

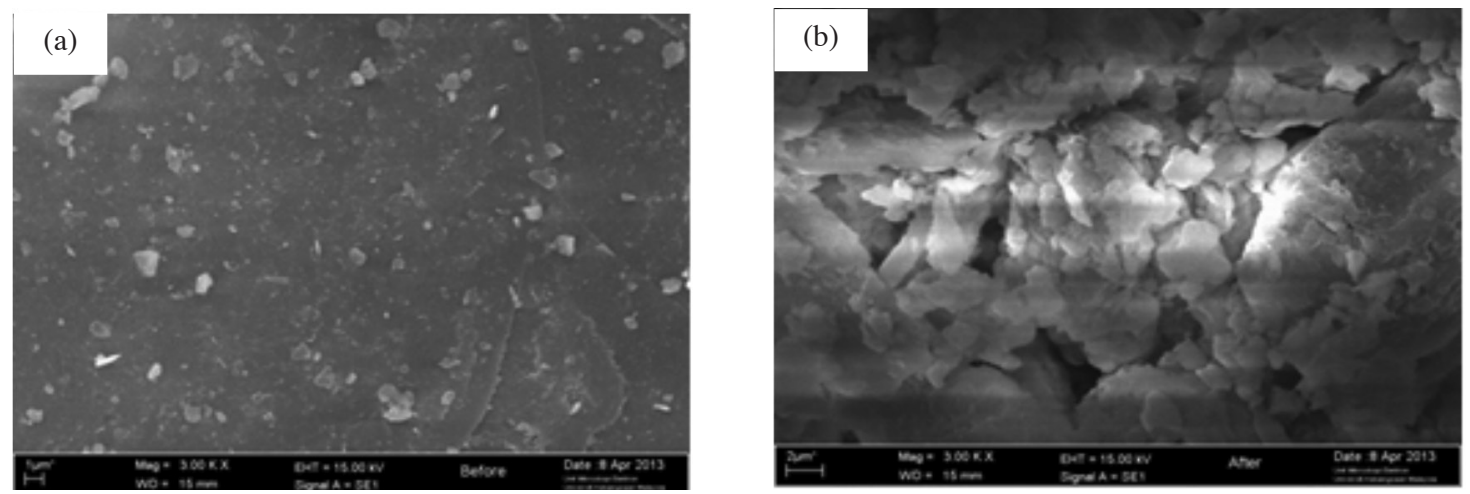

FIGURE 3. The SEM images of Montmorillonite (a) before treatment and (b) after treatment

In the decantation process, the separation of suspended solids from solution was not successful compared to ultrafiltration and adsorption. This was due to low viscosity of POME solution. To increase the viscosity, it can be done by adding some coagulant and flocculants in the POME sample prior to decantation process.

\section{AFTER NANOFILTRATION TREATMENT}

Two membranes, named NF-1 and NF-ASP, were investigated in this research. The real value is shown in Tables 3 and 4, while the percentage is in Figure 4(a) and 4(b). Table 2 shows the reduction value of COD, TSS and colour and turbidity in POME after the nanofiltration treatment. All the pre-treatment methods were successful in removing the suspended solids from POME solution. The adsorption was better than the ultrafiltration for removing the COD and colour, while for the decantation it needs more treatment to reduce the contaminants.

From Figures 4(a) and 4(b), NF-1 membrane has better capability to remove the foulants. Abuhabib et al. (2012) determine the NF-1 has better rejection capabilities than NF-ASP30. It means the NF-1 is more suitable to remove the foulants.

The combination of adsorption and Nanofiltration showed the highest reduction for all parameters. However, the adsorption treatment needs the sedimentation time to settle down the suspended solids. In addition, the adsorbent cannot be reused after reached saturation stage which consequently required more cost and waste the time to replace the adsorbent. In contrary, the combination of ultrafiltration and nanofiltration continuously produced a good quality of POME in a shorter time. The ultrafiltration method can also reduce the cost consumption because the membrane can be cleaned. The combination of decantation and NF showed the worst efficiency compared with the adsorption-NF and UF-NF. Although the coagulation and flocculation can enhance the reduction performance, but the operation of decanter required high energy consumption.

\section{FLUX DECLINE OF NANOFILTRATION MEMBRANE}

Two nanofiltration membranes, named NF-1 and NFASP30 were used to determine the flux decline. Both of nanofiltration membrane was tested after the pre-treatment of POME. For each of membrane, the experiment was run at applied pressure of 10 bars, stirring at $300 \mathrm{rpm}$, retention time of $150 \mathrm{~min}$ without heating effect and $\mathrm{pH}$ adjustment. Figure 5(a) and 5(b) shows the flux decline of NF-1 and NF-ASP30, respectively. From the figures, the permeate flux declined for the pre-treatment POME from

TABLE 3. The POME content after treatment with NF-1

\begin{tabular}{lcccc}
\hline Parameter & Raw Sample & UF+ NF-1 & Adsorption+ NF-1 & Decantation + NF-1 \\
\hline COD (mg/L) & 12040 & 325.3 & 156.7 & 461.0 \\
TSS (mg/L) & 3103 & 1.4 & 1.5 & 35.0 \\
Colour (PtCo) & 54200 & 174.0 & 83.3 & 803.3 \\
Turbidity (NTU) & 23750 & 0.6 & 0.4 & 12.0 \\
\hline
\end{tabular}

TABLE 4. The POME content after treatment with NF-ASP30

\begin{tabular}{lcccc}
\hline Parameter & Raw Sample & UF+ NF-ASP & Adsorption+ NF-ASP30 & Decantation + NF-ASP30 \\
\hline COD $(\mathrm{mg} / \mathrm{L})$ & 12040 & 327 & 163 & 740 \\
TSS $(\mathrm{mg} / \mathrm{L})$ & 3103 & 1.7 & 1.3 & 56 \\
Colour $(\mathrm{PtCo})$ & 54200 & 157 & 117 & 1320 \\
Turbidity (NTU) & 23750 & 0.62 & 1.32 & 195 \\
\hline
\end{tabular}


(a)

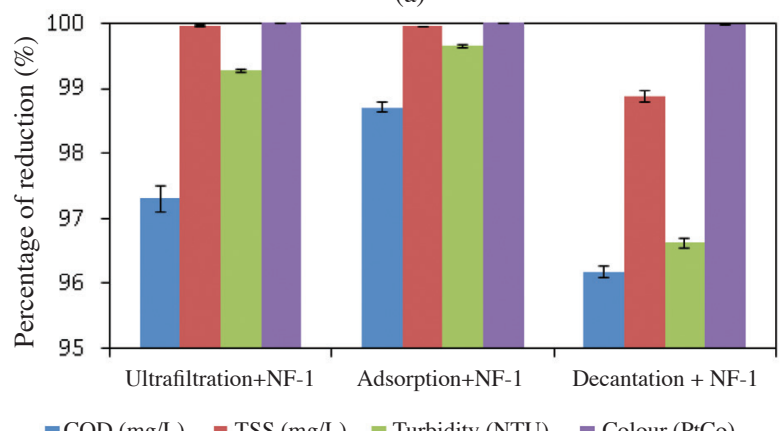

(b)

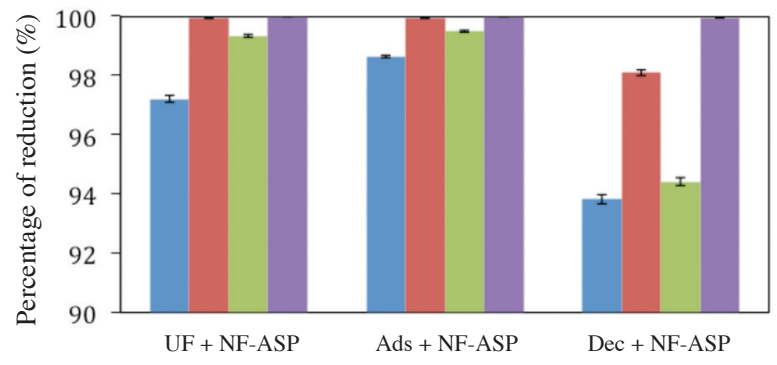

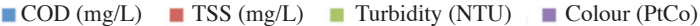

FIGURE 4. Percentage reduction after treatment with (a) NF-1 and (b) NF-ASP

(a)

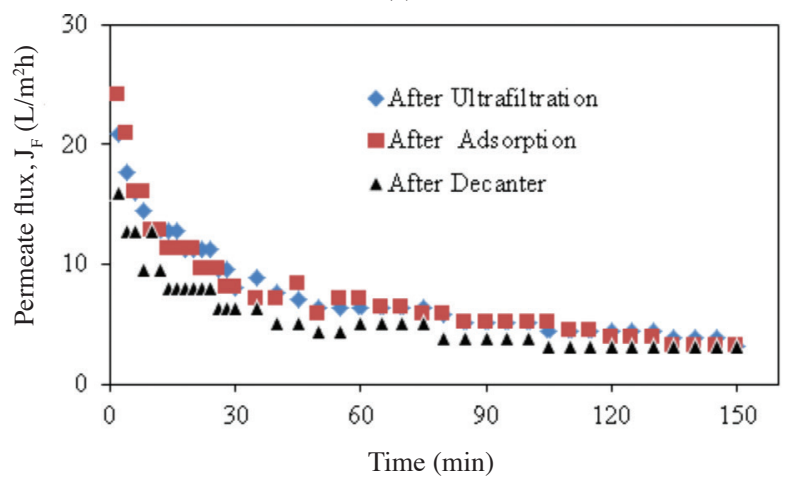

(b)

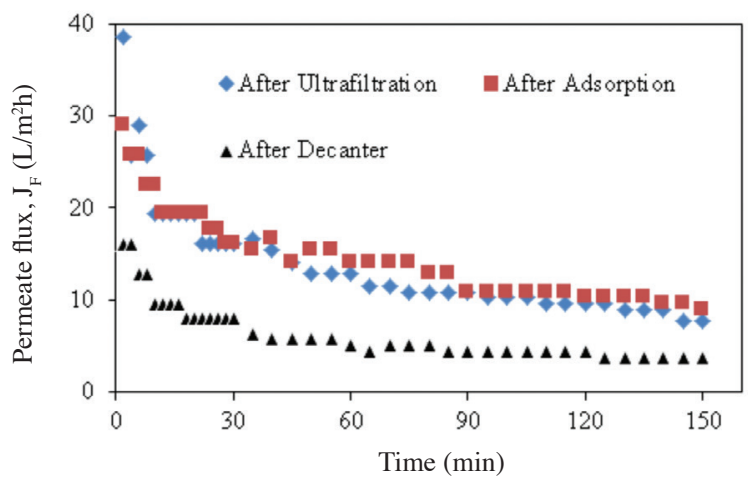

FIGURE 5. The flux decline after NF treatment (a) NF-1 and (b) NF-ASP
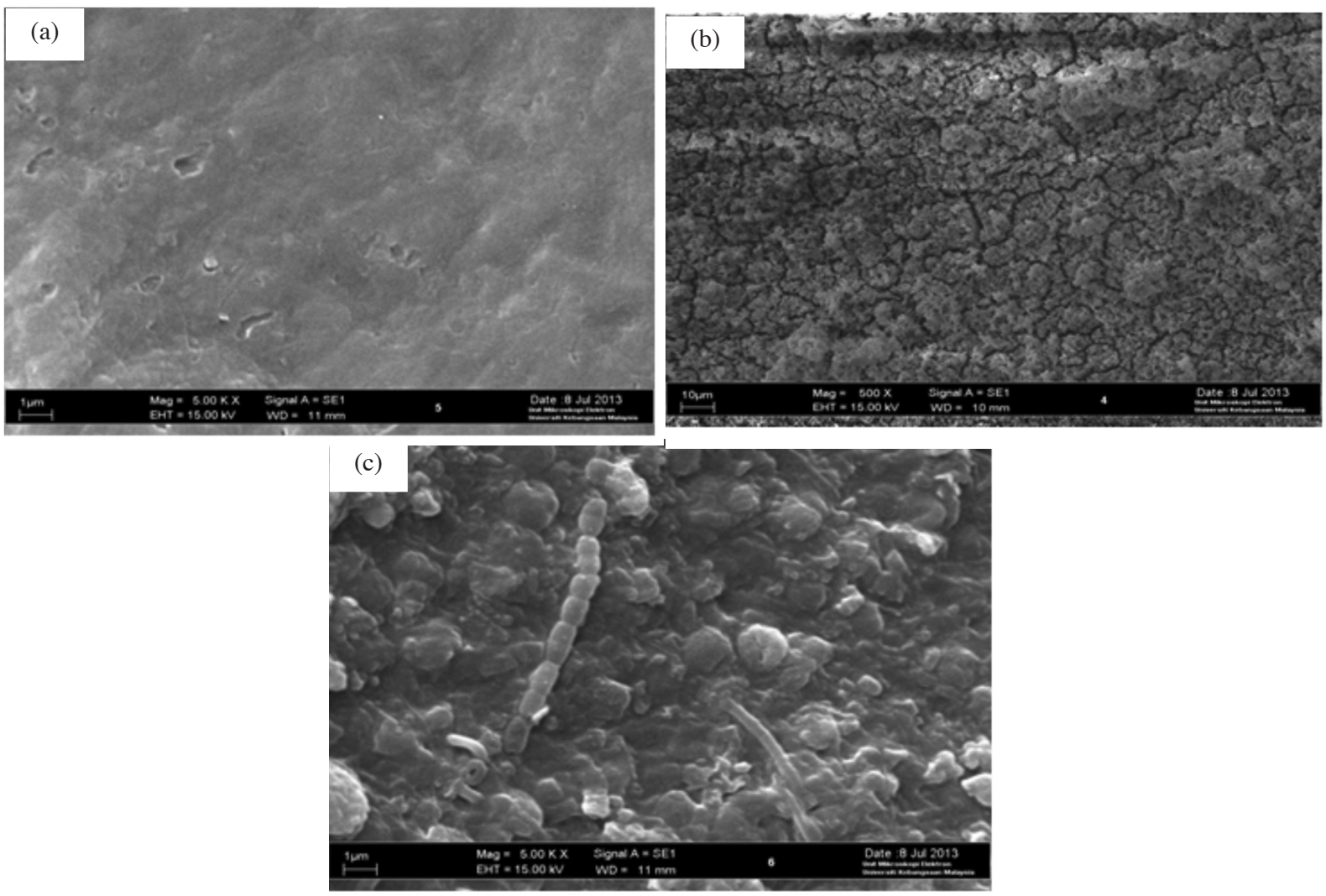

FIGURE 6. The SEM images of NF membrane (a) after ultrafiltration, (b) after adsorption and (c) after decantation 
ultrafiltration, adsorption and decanter. As can be seen from both figures, the pre-treatment POME after ultrafiltration and adsorption showed a higher flux declined compared with the decanter pre-treatment. This phenomenon shows that the ultrafiltration and adsorption pre-treatment can reduced the solids in the POME solution.

The flux of NF-1 membrane was higher than NFASP30 membrane for all pre-treatment methods. This is because of the characteristic correlation of membranes. There are two types of membranes, i.e. hydrophilic and hydrophobic membranes, where the hydrophilic membrane has a weak-bonding with the solids. The NF-1 membrane was hydrophilic membrane while NF-ASP30 was the hydrophobic membrane. Thus, it's explained why the permeate flux from NF-1 higher that the NF-ASP30.

The deposit of solids on the surface of NF-1 and NF-ASP30 membranes caused a clogging problem, consequently raised the permeate flux. This was proved through SEM images on the membranes (Figure 6). The SEM images of NF after ultrafiltration and adsorption pretreatment showed a more clearer (fewer solids) than the decanter.

\section{CONCLUSION}

The combination of three different pre-treatments with nanofiltration show a good results in removal of COD, TSS, colour and turbidity from POME. The combination adsorption and nanofiltration showed the highest reduction but the combination ultrafiltration and nanofiltration was much better in term of cost and operation times. On average, more than $90 \%$ of the parameter can be removed by the pre-treatment stage. Both of NF membranes, NF-1 and NF-ASP, produced an equivalent quality of water after treatment. The final effluent quality of COD, TSS, colour and turbidity closed to the regulated limits for watercourse discharge. The NF-1 was a hydrophilic membrane which had a higher permeates flux compared than NF-ASP30. But NF-ASP has stability in flux decline. Overall, the NF-1 show better performance than NF-ASP.

\section{ACKNOWLEDGMENTS}

The authors would like to thank Universiti Kebangsaan Malaysia for the financial support through program Beasiswa Zamalah Universiti Penyelidikan.

\section{REFERENCES}

Abuhabib, A.A., Mohammad, A.W., Rahman, R.A. \& Shafie, A.H. 2012. Nanofiltration membrane modification by UV graftng for salt rejection and fouling resistance improvement for brackish water desalination. Desalination 295: 16-25.

Ahmad, A.L., Bhatia, S., Ibrahim, N. \& Sumathi, S. 2005. Adsorption of residual oil from palm oil mill effluent using rubber powder. Brazilian Journal of Chemical Engineering 22: 371-379.

Ahmad, A.L., Bhatia, S. \& Ismail, S. 2003. Water recycling from palm oil mill effluent (POME) using membrane technology. Desalination 157: 87-95.
Ahmad, A.L., Sumathi, S. \& Hameed, B.H. 2006. Coagulation of residue oil and suspended solid in palm oil mill effluent by chitosan, alum and PAC. Chemical Engineering Journal 118: 99-105.

Ahmaruzzaman, M. 2008. Adsorption of phenolic compounds on low-cost adsorbents: A review. Advances in Colloid and Interface Science 143: 48-67.

Ahmed, S., Rasul, M.G., Hasib, M.A. \& Watanabe, Y. 2010. Performance of nanofiltration membrane in a vibrating module (VSEP-NF) for arsenic removal. Desalination 252: 127-134.

Amin, I.N.H., Mohammad, A.W., Markom, M., Leo, C.P. \& Hilal, N. 2010. Flux decline study in UF of glycerin-rich fatty acid solutions. Journal of Membrane Science 351(1-2): 75-86.

Borja, R. \& Banks, C.J. 1995. Comparison of an anaerobic filter and an anaerobic fluidized bed reactor treating palm oil mill effluent. Process Biochemistry 30: 511-521.

Borja, R., Banks, C.J. \& Sanchez, E. 1996. Anaerobic treatment of palm oil mill effluent in a two-stage up-flow anaerobic sludge blanket (UASB) system. Journal of Biotechnology 45(2): 125-135.

Chan, Y.J., Chong, M.F. \& Law, C.L. 2010. Biological treatment of anaerobically digested palm oil mill effluent (POME) using a lab-scale sequencing batch reactor (SBR). Journal of Environmental Management 91: 1738-1746.

Gönder, B.Z., Arayici, S. \& Barlas, H. 2011. Advanced treatment of pulp and paper mill wastewater by nanofiltration process: Effects of operating conditions on membrane fouling. Separation and Purification Technology 76(3): 292-302.

Hameed, B.H., Ahmad, A.L. \& Hoon, N.A. 2003. Removal of residual oil from palm oil mill effluent using solvent extraction method. Jurnal Teknologi 38: 33-42.

Najafpour, G., Yieng, H.A., Younesi, H. \& Zinatizadeh, A.A. 2005. Effect of organic loading on performance of rotating biological contactors using palm oil mill effluents. Process Biochemistry 40: 2879-2884.

Ng, W.J., Goh, A.C.C. \& Tay, J.H. 1988. Palm oil mill effluent treatment-liquid-solid separation with dissolved air flotation. Biological Wastes 25: 257-268.

Said, M., Mohammad, A.W., Nor, M.T.M., Abdullah, S.R.S. \& Hasan, H.A. 2014. Chemical cleaning of fouled polyethersulphone membranes during ultrafiltration of palm oil mill effluent. Membrane Water Treatment 5(3): 207-219.

Susanto,H. 2011. Towards practical implementations of membrane distillation. Chemical Engineering and Processing: Process Intensification 50(2): 139-150.

Vijayaraghavan, K., Ahmad, D. \& Aziz, M.E.A. 2007. Aerobic treatment of palm oil mill effluent. Journal of Environmental Management 82: 24-31.

Wei, X., Wang, Z., Fan, F., Wang, J. \& Wang, S. 2010. Advanced treatment of a complex pharmaceutical wastewater by nanofiltration: Membrane foulant identification and cleaning. Desalination 251: 167-175.

Wah, W.P., Sulaiman, N.M., Nachiappan, M. \& Varadaraj, B. 2002. Pre-treatment and membrane UF using treated palm oil mill effluent (POME). Songklanakarin J. Sci. Technol. 24: 891-898.

Wu, T.Y., Mohammad,A.W., Jahim, J.M. \& Anuar, N. 2007. Palm oil mill effluent (POME) treatment and bioresources recovery using UF membrane: Effect of pressure on membrane fouling. Biochemical Engineering Journal 35(3): 309-317.

Yejian, Z., Li, Y., Xiangli, Q., Lina, C., Xiangjun, N., Zhijian, M. \& Zhenjia, Z. 2008. Integration of biological method 
and membrane technology in treating palm oil mill effluent. Journal of Environmental Sciences 20: 558-564.

Zinatizadeh, A.A., Mohamed, A.R., Mashitah, M.D., Abdullah, A.Z. \& Najafpour, G.D. 2006. Pretreated POME digestion in an up-flow anaerobic sludge fixed film bioreactor: A comparative study. IJE Transactions B: Applications 19: 1-9.

\section{Muhammad Said}

Department of Chemistry

Faculty of Science and Mathematics

University of Sriwijaya

Palembang 30662

Indonesia
Abdul Wahab Mohammad*, Mohd Tusirin Mohd Nor, Siti Rozaimah Sheikh Abdullah \& Hassimi Abu Hasan Department of Chemical and Process Engineering Faculty of Engineering and Built Environment Univesiti Kebangsaan Malaysia 43600 Bangi, Selangor Darul Ehsan Malaysia

*Corresponding author; email: wahabm@eng.ukm.my

Received: 8 January 2014

Accepted: 3 September 2014 